\title{
ZSOLNAI EMLÉKKONFERENCIA
}

\author{
KISS ÉVA \\ a Pannon Egyetem Neveléstudományi Intézet ÉKP Központjának \\ ügyvivő szakértője \\ kisse@almos.vein.hu
}

Tudományos emlékkonferenciát szervezett a közelmúltban elhunyt $d r$. Zsolnai József tiszteletére a Magyar Tudományos Akadémia Neveléstudományi Bizottsága, az Oktatáskutató és Fejlesztő Intézet, valamint a konferenciának otthont adó Pannon Egyetem. Szinte napra pontosan 5 hónappal a halála után tartották meg. A Veszprémi Akadémiai Bizottság Székházának díszterme megtelt munkatársakkal, pályatársakkal, tanítványokkal, tisztelőkkel.

Zsolnai József életének utolsó évtizede a Pannon Egyetemhez (korábban Veszprémi Egyetem) kötődött. Az egyetem Pápán 1999-ben alapította Tanárképző Karának keretei között a Pedagógiai Kutatóintézetét, melyet Zsolnai József vezetett. Zsolnai József nem kisebb feladatot vállalt magára, mint azt, hogy a nagy múltú iskolavárosba visszatelepíti a pedagógusképzést a város és az egyetem vezetőinek támogatásával. Megtette, megtették. Pápán a kicsi egyetemi kampuszon 2003-tól neveléstudományi doktori képzést vezetett Zsolnai József A pedagógusképzés pedagógiája és az Anyanyelv- és irodalompedagógia alprogramban. 2006-tól Pedagógia alapszakon és Neveléstudomány mesterszakon is folyik itt képzés.

Horváth H. Attila Zsolnai Józsefröl mint a doktori iskola két alprogramjának vezetőjéről beszélt. Szólt az évente rendezett mühelykonferenciákról, amelyeken a doktoranduszok nem csak saját az évi kutatási teljesítményeikről számoltak be, hanem egymás kutatásainak opponenseként is gyakorolták a majdani tudományos élet szerepeit. „Azt gondolom, hogy ez egyik értéke volt doktori iskolánknak. ... Abba a tudományfelfogásba, amely mentén kívülről is és a hallgatók egymás közt is 'Zsolnai iskolának' hívták, jellemző mozzanat volt."

A vendégeket $d r$. Mihalovics Árpád a Pannon Egyetem rektorhelyettese köszöntötte, bemutatva Zsolnai József szakmai életútjának fó csomópontjait. Azután 25 előadó a gazdag tematikájú Zsolnai életmühöz, életúthoz tartozó egy-egy állomáshelyet, teljesítményt, szakmai eseményt villantott fel, amelyen Zsolnai Józseffel közösen munkálkodtak vagy közösen voltak részesei annak. A 25 előadás mindegyikét itt nem mutathatjuk be, csak néhánynak a felidézésére van lehetőség. Azonban a video.ofi.hu portálon az összes értékes előadás megnézhető.

Mátrai Zsuzsa professzor asszony előadása elején egy korábbi előadását idézte fel, amelyben a 70 éves Zsolnai Józsefet köszöntve azt állította, hogy a Zsolnai- 
pedagógia lényegének a reverzibilitást (megfordíthatóságot) tekinti. „Amit én úgy értettem, hogy Zsolnai az, aki újból és újból fölteszi az alapkérdéseket, és nagyon gyakran megfordítja rá a válaszokat, magyarán: új válaszokat ad." A nagyon eredeti, a Zsolnai József intellektusát és karakterét elemző előadásból csak Zsolnai Józsefnek a kutatáshoz való viszonyáról mondottaknak elemeit idézzük. „Aki kapcsolatban volt vele az pontosan tudja, hogy a kutatás nála egy alaptéma volt ... Zsolnai két kérdést tett föl: kell-e kötni a kutatási képességek fejlesztését az absztrakt fogalmi gondolkodáshoz ... 12-13 éves kortól, ahogy ez Brunernél megjelent? A válasz az volt, hogy nem. ... A másik kérdés, amit föltett, hogy csak a kutatói pályára készülőknek kell-e a kutatás, vagyis privilégium-e a kutatási képességek tanítása, fejlesztése? Erre is az volt a válasza, hogy nem. ... Az egészet ő azért csinálta, mert nem kutatókat akart ő a gyerekekből képezni, ... hanem úgy gondolta, hogy a kutatási képességek fejlesztése az az életre készít fel. ... A másik példám az a kutatás - fejlesztés kapcsolatáról szól. ... a kérdése az volt, hogy megelőzi-e a kutatást a fejlesztés. ... (A szokványos válasz az, hogy igen.) Az ő válasza nagyon érdekes volt: nem, egymást görgetik elöre. Ez nem volt más, mint maga az akciókutatás. Az ő akciókutatás-fölfogásában nem vált el a kutatás a fejlesztéstöl, hanem a fejlesztési célokból lettek a kutatási témák, és a kutatási témákból lettek a fejlesztési célok. Azt hiszem, hogy ez volt a lényege az ő akciókutatás-felfogásának.”

Lengyel Zsolt professzor, aki 1999-ben dékánként Zsolnai Józsefet és kutatócsoportját a Veszprémi Egyetem Tanárképző Karára telepítették, s együtt a Pápai Pedagógiai Kutatóintézetet kialakították és létrehozták, az Anyanyelvi nevelés: szóasszociációk címủ kiváló kutatását mutatta be. A kutatás első szakaszában a korpusz egy részét Zsolnai-iskolákba járó (ÉKP ${ }^{1}$-s) gyerekektől nyerte - nyilván Zsolnai József közremüködésével.

Kaposi József az Oktatáskutató és Fejlesztő Intézet föigazgatója tisztelgett elödje, a vezetése alatt müködő intézmény egyik alapítója előtt. Hiszen 1990-ben, a rendszerváltás nehezen átlátható időszakában kapott megbízást Zsolnai József az Országos Közoktatási Intézet (OKI) megszervezésére, s föigazgatóként vezette azt 1995-ig. Kaposi József szerint a Zsolnai József által 1990-ben föigazgatóként deklarált értékek ma is érvényesek. Kaposi József a kutató-fejlesztő szerepében $A$ drámajáték címmel tartott előadást, melyben röviden értékelte a Zsolnai-programokban a gazdag fejlesztési lehetőségei miatt fontos szereppel bíró színjátszás és mimetikus játék tantárgyi programokat (divatos szóhasználattal élve: modulokat).

Géczi János egyetemi docens, tanszékvezető, az Iskolakultúra c. folyóirat föszerkesztője a rendszerváltást követő időszak országos oktatási intézményeinek átalakulását, vezetőik hatalmi helyzetét, és az oktatási szakfolyóiratok helyzetének és profiljának alakulását is felidézte. „Az Iskolakultúrának azt a szakaszát szeretném áttekinteni '91-től '98-ig, amikor Zsolnai Józseffel a lappal kapcsolatban nagyon

\footnotetext{
${ }^{1}$ Értékközvetítő és képességfejlesztő program.
} 
szorosan együttmüködtünk. Vagyis attól a pillanattól, amikor alapító kiadóként létrehozta a lapot, addig a pillanatig, amikor eltávozott Pécsi Egyetemről. ... A folyóirat koncepciójával, interdiszciplináris jellegével, a Zsolnai által is képviselt holisztikus elképzeléssel." Az Iskolakultúra, a lektorált folyóirat felépítését, szerzőinek alakulását, a kéziratok jellegének és minőségének változását a fenti kontextusba ágyazottan mutatta be. „Megjegyzem: Tanár úr soha nem szólt bele a lap szerkesztésébe. Többször vitatkoztunk. ... Ezek a viták, beszélgetések eredményezték azt, hogy egy kritikai attitüdöt egyre inkább felvállalt a lap.”

Kamarás István szociológus kutató arról számolt be, hogy a Zsolnai József által A pedagógia új rendszere címszavakban címü monográfiában körvonalazott hiányzó és kidolgozandó pedagógia diszciplínák kidolgozását vállalta magára. Ezek közül a pedagógiai filozófiát mint pedagógiai alaptant már elkészítette. Az 1990-től intenzív szakmai kapcsolatuk Pannon Egyetemhez kötődő szakaszáról így szólt: „Zsolnai tanár úr néhány évvel ezelőtt megkért, hogy a PE Neveléstudományi doktori iskolájában Pedagógiai etika kurzust tartsak. Ehhez nekem nem volt elegendő munícióm. A múlt évben az ö munkatársai egy kutatás keretében megkértek, hogy írjak egy tanulmányt Pedagógiai etika címmel. ... Ez meg is született: Szempontok és adalékok egy értékközvetitő és képességfejlesztő irányultságú pedagógiai etikához címmel ... egy könyvecske ... A Zsolnai József által kidolgozott értékközvetító és képességfejlesztő irányultságú pedagógiában a közvetítés egyben értékrendalapitás és értékteremtés is. Az érték pedig nála - legtöbb esetben - erkölcsi érték, a közvetítendö képességek körében benne vannak nála az erkölcsi készségek, vagyis az erények. Egy ilyen irányultságú pedagógiából kinöveszthető egy pedagógiai etika. Az ö nyomdokán próbáltam ennek eleget tenni." Kamarás István a pedagógiai etika kimunkálásán dolgozik, s ennek jól kirajzolódó kontúrjait ismertette.

Balázs Éva, Vágó Irén és Kocsis Mihály több mint 3 évtizedig dolgoztak Zsolnai Józseffel - már az Oktatáskutató Intézet megalakulásától. Az idő a gazda mindenben c. közösen jegyzett elöadásukat Kocsis Mihály, az OFI központigazgatója tolmácsolta. Bemutatta azokat az intézményeket, amelyekben együtt dolgoztak; azokat a munkákat, amelyeken együtt dolgoztak. Az utolsó közös munkát Az olvasás, a szövegértés és az internet pedagógiai tartalékainak feltárása címủ kutatást, amelyet 2009-ben Zsolnai József indított el, külön megemlítette. E kutatás lezárásában Zsolnai József már nem vehet részt. Kocsis Mihály ezután tételesen felidézte a nagyobb és jelentősebb közös munkákat, összevetve kurrens témáik megjelenésének vagy a gyakorlatban való kipróbálásuk, alkalmazásuk, müvelésének időpontjait az oktatáskutatás nagy nemzetközi folyamataiban való megjelenésük időpontjával. Ezen összehasonlításokból kiderül, hogy Zsolnai József kutatási problémáinak felvetésével, a pedagógiai $\mathrm{K}+\mathrm{F}+\mathrm{I}$ megvalósításával jó néhány esetben akár 1-3 évtizeddel megelőzte a nemzetközi oktatáskutatásokat is. E témák pl.: a pedagógiai tudás, a pedagógustudás, a pedagógiai akciókutatás, a tanulásfölfogás, a hátrányenyhítés, a te- 
hetségfejlesztés és az inklúzió együttes gyakorlata, a tanulás tanítása, a pedagógiai innovációtípusok sokasága ....

Vass Vilmos, az ELTE egyetemi docense először arról szólt, hogy „Az interdiszciplinaritás Zsolnai József munkáiban az egyik leggyakoribb szó. Az interdiszciplinaritás tudományelméleti és pedagógiai megközelítéséről érdemes eszmét cserélni." S mivel Vass Vilmos a tantárgyköziséggel foglalkozik, magától értetődött, hogy izgalmasnak találta az ízig-vérig interdiszciplináris gondolkodású Zsolnai Józseffel a szakmai párbeszédet. Személyes szakmai megemlékezésében a NEB-röl, a Nagy Esti Beszélgetéseiknek rítusáról beszélt. „Én alig vártam ezeket a nagy esti beszélgetéseket. A legelső beszélgetésünk a kompetenciafogalom körül forgott. Hihetetlenül izgalmas volt megtapasztalni, hogy a kompetencia kérdéskörét lehet más szemüvegen át is nézni. Akkor én tettem egy tétova ígéretet Professzor úrnak. Azt mondtam, hogy 2 év múlva elhozom Pápára az Európai Unió Kulcskompetencia Bizottságát, és folytassuk velük tovább ezt a beszélgetést. Ez a pedagógiai megközelítés megtörtént. 2007-ben az Európai Unió Kulcskompetencia Bizottsága tiszteletét tette Pápán. A professzor úr készített egy hihetetlenül alapos, anyagot a kompetenciáról. Ebben a kulcskompetencia-területek hiányaként említi a sportot mint a személyiséget formáló tevékenységet, amely segít, hogy egészségben és mentálisan is jobban éljünk. Továbbá: ne csak gazdasági szempontok vezéreljék az életünket, hanem jelesül társadalmi, erkölcsi szempontok is. Ezt ott a nemzetközi szakembergárda méltán üdvözölte.”

Györe Géza bibliográfus, a PE Neveléstudományi Intézet könyvtárvezetője - aki szintén a Zsolnai-féle doktori képzésben szerzett PhD minősítést - Zsolnai Józsefröl, a bibliofilről, a könyvtárosról, a könyvtárpedagógia alapozójáról és a tudománypedagógusról emlékezett meg. Ezután Könyvtári témák a Zsolnai életműben és a Zsolnai-életmü bibliográfia címmel ismertette saját munkáját: 71 év 855 tétele. Zsolnai József-bibliográfia címü kiadványának készítése közben felmerülő problémákat, és a Zsolnai-bibliográfiával kapcsolatos további kutatási teendőket, melyek elsősorban rá várnak.

Kiss Albert, a Zalabéri Általános Iskola igazgatója a nagyhírü Törökbálinti Kísérleti iskolában kezdte tanári pályáját 1986-ban. Az iskola igazgatója és kutatásvezetője, Zsolnai tanár úr azzal bízta meg, hogy foglalkozzon az általános iskolások kutatásra nevelésének, tehetségfejlesztésének programjával. 1990-től zalabéri igazgatóként és Zsolnai József kutatótársaként az ő útmutatásai alapján zalabéri tanártársaival kialakították a 10-14 éves gyerekek kutatóvá nevelésének a programját, melyet a Pannon Egyetem Neveléstudományi Intézet Értékközvetítő és Képességfejlesztő Program Országos Központjának kutatóiskolájaként és annak munkatársaival együttmúködve országos mozgalommá fejlesztettek (előbb Tudományos Diákkör 10-14 éves gyerekek számára, jelenleg Kutató Gyerekek Tudományos Köre néven). 
Falus Iván pedagóguskutató felidézte több évtizeddel ezelőtti első „találkozását" Zsolnai Józseffel. A Köznevelésben olvasva róla olyan érzése támadt, hogy „valahol az az állóvíz, ami körülvesz bennünket, mozdulni látszik”. Zsolnai József egy olyan iskolát vizionált, amelyik minőségi iskola, ahol minőségi pedagógusok vannak. 2 évvel később megismerkedett Zsolnai Józseffel Kaposváron, s hajnalig tartó pedagógiai vitát folytattak. Aztán pályájuk közös szakaszáról szólt, amely annyiban biztos közös volt, hogy azonos témával foglalkoztak. „Ha az ember valamilyen szakmára fel akar készíteni embereket, akkor először ezt a szakmát le kell írnia, elemeznie kell, meg kell mérnie, hogy mi az a tudás, mik azok a képességek, amire szükség van ahhoz, hogy erre a területre fel lehessen készíteni a jövendö szakembereit. ... Zsolnai József pécsi évei alatt munkatársaival együtt összegyüjtötte a különböző szaktárgyakat tanító pedagógusok fö tevékenységelemeit, s ezeket nevezte professziogramnak. Mi az ELTE-n szintén kidolgoztunk egy algoritmust, amelynek a segítségével el lehetett jutni ahhoz a célrendszerhez, amely a gyakorlat számára készítené fel a megfelelő pedagógusokat. Ennek az algoritmusnak egy lényeges eleme volt szintén a professziogram.” Kutatásaikban más-más eszközökkel dolgoztak, más-más irányban folytatták. De - mint Falus Iván mondta -: „amikor ezen szoktam gondolkodni, sokszor arra gondoltam, hogy milyen jó lett volna ezt a nagy szabású kutatást közösen elvégezni."

Pastyik István történész szerint „Zsolnai az 1960-as években üstökösként vonult végig Dunapataj egén. ... Zsolnai az alatt a pár esztendő alatt ugyancsak megkavarta a posványos vizeket. Mi jellemezte őt? Az alaposság. Az elképesztő alaposság. ... Nem kiabált, de elképesztően szigorú volt. Igényes volt. Hasonlóan, mint Kodály. Csöndes szavú ember volt, hallatlan igényességgel. Nagyon jól tudott bánni mindenkivel. Megértette a nyelvét. És ugyanúgy közelített a kisgyerekhez, mint a nagyhoz is. Szédületes területet pásztázott be a tudása. Olyan volt, mint az az épület, amelyben sok helyen, majdnem minden szoba sarkába erős alapokat raknak le, hogy az egész épület szilárdan álljon."

Tóthpál József müvészetfilozófus a szegedi tanítóképzőben volt iskolatársa Zsolnai Józsefnek. Az 1990-es évektől kezdődő közös pályájuk ismertetéseként, arról szólt, hogy az ÉKP-programon belül müvészettörténeti, müvészetpedagógiai témák gondozására, ezek pedagógiájának megújítására kérte fel Zsolnai József. E munka keretében „2008-ban volt egy ÉKP-s konferencia Szolnokon, ahol egy előadást tartottam a Müvészetpedagógia ethosza címmel, a müvészetfilozófia forrásait feltárva különböző elgondolásokat vázoltam. Ennek azután már nem volt következménye. Zsolnai József akkor már kezdett megbetegedni, és nem tudtunk a témáról a továbbiakban tárgyalni. ... Ha most látleletet veszünk arról, hogy mi történt Magyarországon a müvészetpedagógiában és különös tekintettel a pedagógiában, akkor azt kell mondanom, hogy egy apály jelei mutatkoznak 8-10 esztendeje. ... Akkor lehetünk hívek ahhoz a programhoz, amit Zsolnai József megfogalmazott, ha a müvészetpedagógia területét müvelök, a müvészetpedagógiával foglalkozó ta- 
nárok végiggondolják, hogy hogyan tovább. Akkor talán képesek lehetünk egy megújulásra.

Elhangzottak még a következő előadások: Koltai Dénes: Zsolnai József a Pécsi Tudományegyetemen; Kurtán Zsuzsa: Tudományos nyelvhasználat és pedagógia; Czakó Kálmán Dániel: A természettudományos tárgyak oktatása - Integráló szándék a tanításban; Bognárné Kocsis Judit: Az ideális pedagóguskép jellemzői; Monoriné Papp Sarolta: A tanóra-diagnosztikai modell; Bánhidi Miklós: Értékképzés és sporttudomány; Katona László: Az alkalmazott színház és a nyelvtanárképzés; Ásványi László: Iskolaváros - iskolaország, valamint Burián Miklós: Laudáció.

Géczi János zárta az emlékkonferenciát. „Zsolnai tanár úrra emlékezünk. mindig ült, amikor előadott... Mi volt ő? Pedagógus volt? Tudós volt? Persze. Szerintem ő ennél több is volt. Mủvész volt. Azt a müvészetet, amit meg lehetett élni, azt ő megélte. Bizonyítékom is van arra, hogy az volt. ... Egy barátjától kaptam megy egy dramatikus mủvét. Nem tudom, hogy rádiójátéknak készült-e, drámának készült-e. Az, hogy én szociológiával foglalkoztam, ez részben ennek is köszönhetö. Azokban a tárgyakban, amelyekkel körülvette magát, „müvész-szerüségét” is használta. ... A sorsnak a véletlen eredményeképpen Tanár úr a Pannon Egyetem két helyszínén: Pápán és Veszprémben is élhetett szinte utolsó napjáig. A Pannon Egyetem tudatában van ennek az örökségnek. Mind a rektor úr, mind pedig a dékán úr ezt az örökséget a mi egyetemünk fölvállalja. Bécsy Tamás mellett egy másik nagy személyiséggel is a történelmünket meg kell alkotni. A Zsolnai-örökségnek a megtartásához kérem a szakma segítségét, a tanítványok és a kollégák segítségét, hogy nagyon pontosan tudjunk visszaemlékezni rá. Ehhez talán mi is hozzá tudunk járulni: ősszel az alapító kiadónkat azzal is megtiszteljük, hogy a konferenciáról egy külön Iskolakultúra szám jelenik meg. Remélem, hogy hamarosan találkozhatunk Pápán vagy Törökbálinton vagy bárhol időnként szabadon beszélgetni.” 